\title{
弓部大動脈近傍の術中大血管損傷の治療
}

\author{
一超低体温循環停止法の有用性一
}

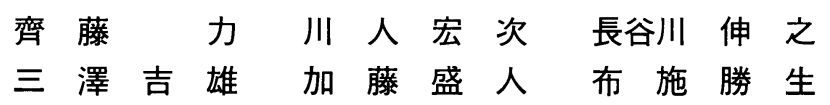

術中予期せぬ弓部大動脈近傍の大血管損傷により, 修復に超低体温循環停止法（一部逆行性脳灌流法 を併用）を用いた 5 例について検討した。症例の内訳は出血性損傷 3 例, 急性解離 2 例であった。修 復および手術遂行に要した体外循環時間は 159〜367 分 (平均 199 分), 循環停止時間は 20 44 分 (平均 32 分), 循環停止温度は膀胱温 $19.5 \sim 22.0^{\circ} \mathrm{C}$ (平均 $21.0^{\circ} \mathrm{C}$ ), 脳保護補助手段として逆行性脳灌 流法を 2 例に使用した。術後覚醒までの時間は持続鎮静降圧療法を施行した症例 1 を除き 4 ９時間 で, 全例神経学的合併症はみられず退院した。超低体温循環停止法は, (1 ) 血管壁の緊張緩和.（2） 良好な無血視野. (3) 自己血回収が可能. (4) 低体温による臓器保護. などの利点がある. 従って本 法は弓部大動脈近傍の大血管損傷の修復に際して, 重大な合併症を回避しうる可能性があり, 遮断鉗 子下での修復が困難な場合には速やかに選択すべき方法と考えられた. 日心外会誌 27 巻 6 号 : 360363 (1998)

Keywords：超低体温循環停止法, 大動脈損傷, 逆行性脳灌流法

\section{Surgical Management of Aortic Arch Injury Complicating Cardiovascular Surgical Operations Utilizing Hypothermic Circulatory Arrest}

Tsutomu Saito, Koji Kawahito, Nobuyuki Hasegawa, Yoshio Misawa, Morito Kato and Katsuo Fuse (Department of Thoracic and Cardiovascular Surgery, Jichi Medical School, Tochigi, Japan)

Injuries to the aorta complicating cardiovascular operations can be very challenging. This type of injury is usually related to manipulation of the aorta during surgical exposure or aortic cannulation. From March 1994 to October 1997, five patients with intraoperative injuries to the thoracic aorta occurred. Their ages ranged from 7 to 71 years old (mean, 43.5 years). Two were male and 3 female. Intraoperatively, trouble occurred suddenly due to acute aortic dissection related to aortic traumatic hemorrhagic disruption in three patients, and aortic cannulation in two patients. The confirmation of the diagnosis was prompted clinically, and all patients immediately underwent further surgical intervention. In terms of technique, we used a cardiopulmonary bypass (mean cardiopulmonary bypass time $239 \mathrm{~min}$, range 196 to $367 \mathrm{~min}$ ), and hypothermic circulatory arrest (mean arrest time $34 \mathrm{~min}$, range 20 to $44 \mathrm{~min}$, at deep hypothermia with $21.0^{\circ} \mathrm{C}$ urinary bladder temperature) during repair. Retrograde cerebral perfusion was utilized in two cases to assure protection for cerebral damage. Fortunately, there was no postoperative neurological complication and no hospital death in any of the cases. When such intraoperative injuries of the aorta once occur repair using aortic clamps often fail or is not feasible, and in such cases hypothermic circulatory arrest combined with retrograde cerebral perfusion should be applied to resolve this type of the serious troubles. Jpn. J. Cardiovasc. Surg. 27: 360-363 (1998)

心臓大血管手術に際して，弓部大動脈近傍の大 血管損傷が発生した際の修復方法は様々である. このような場合に，超低体温循環停止法（逆行性

1997 年 12 月 24 日受付， 1998 年 6 月 16 日採用 自治医科大学胸部外科 ₹ 329-0431 栃木県河内郡南河内町薬 師寺 3311-1
脳灌流法を伴用したものを含む。以下 HCA と略 す）を用いて修復を試み，その有用性について検 討した。

\section{対象と方法}

1994 年 3 月から 1997 年 10 月までに術中損傷 
表 1 弓部大動脈近傍の大血管損傷症例の内訳

\begin{tabular}{lcccccc}
\hline 症 & 例 & 1 & 2 & 3 & 4 & 5 \\
\hline 年 & 齢 & 24 & 66 & 7 & 46 & 71 \\
性 別 & 女 & 男 & 女 & 男 & 女 \\
術前診断 & 動脈管切離術後 & annuloaortic & 動脈管開存症 & 単心房 & 大動脈弁 \\
& 胸部大動脈破裂 & ectasia & & & & 閉溑不全症 \\
損 & 傷 & 動脈管近傍の & 急性大動脈解離 & 動脈管近傍の & 上行大動脈損傷 & 急性大動脈解離 \\
& 大動脈損傷 & (Stanford A) & 大動脈損傷 & & & (Stanford A) \\
到達方法 & 左開胸 & 胸骨正中切開 & 左開胸 & 胸骨正中切開 & 胸骨正中切開 \\
修復方法 & 直接縫合閉鎖 & 人工血管置換 & 直接縫合閉鎖 & 直接縫合閉鎖 & 人工血管置換 \\
体外循環予定 & あり & あり & なし & あり & あり \\
\hline
\end{tabular}

などで，HCA 下に弓部大動脈近傍の大血管の修 復を行った 5 例を対象とした。症例の内訳は，大 動脈の出血性損傷 3 例, 大動脈解離 2 例であっ た。症例の概要は表 1 に示す.

症例 $1: 24$ 歳女性，動脈管切断術後急性期の感 染性胸部大動脈破裂緊急手術症例。遮断鉗子を用 いた修復が困難なため, 出血点を用手圧迫，体外 循環を確立し HCA 下に修復，加えて大網充填を 施行した。術直後より持続鎮静降圧療法を行っ た'.

症例 $2: 66$ 歳男性, annuloaortic ectasia 待機 手術症例. 大腿動脈送血部分より逆行性に解離, 上行大動脈で破裂出血した。出血点を用手圧迫. 対側大腿動脈送血により体外循環を確立し HCA 下に大動脈基部置換術を行った ${ }^{2}$.

症例 $3: 7$ 歳女性，動脈管開存症の待機手術症 例. 動脈管剥離操作中に近傍の大動脈から出血 し，遮断鉗子を用いた修復が困難なため，出血点 を用手圧迫，体外循環を確立し HCA 下に大動脈 損傷部の直接修復抢よび動脈管離断縫合閉鎖術を 行った。

症例 4：46 歳男性, 单心房待機手術症例. 上行 大動脈送血部分から弓部へ裂け込み出血した。出 血点を用手圧迫，体外循環を確立し HCA 下に直 接修復，心房中隔パッチ形成術を行った。

症例 5：71 歳女性, 大動脈弁閉鎖不全症待機手 術症例.上行大動脈送血部分から逆行性に解離, 体外循環中であったためそのまま HCA とし大動 脈弁置換術に加えて上行大動脈人工血管置換術を 行った。
損傷発生から体外循環開始までの所要時間，体 外循環時間, 循環停止温度 (膀胱温), 循環停止 時間，術中同種血輸血量，術後覚醒までの時間， 気管内チューブ抜去までの日数，経口摂取までの 日数, 神経学的合併症, 術後合併症, 退院までの 日数について検討した。

\section{結果}

術中損傷発生から体外循環開始までの所要時間 は最長 126 分，体外循環時間は 159～367 分（平 均 237 分), 循環停止時の深部体温（膀胱温）は $19.5 \sim 22.0^{\circ} \mathrm{C}$ (平均 $21.0^{\circ} \mathrm{C}$ ), 循環停止時間は 20〜44 分（平均 34 分）であった。また，術後覚 醒までに要した時間は持続鎮静降圧療法を施行し た症例 1 を除き 4 〜時間で，抜管までの日数は 1〜25 日，経口捸取までの日数は 1〜39 日，退院 までの日数は 11〜165 日であった。

術後合併症は，症例 1 では仮性動脈瘤形成のた め遠位弓部大動脈置換術, 症例 2 では左下肢血行 障害に対して両側大腿動脈間バイパス術, 症例 5 では抜管後の声帯浮腫のため気管切開を要した。 脳神経学的合併症は認められなかった（表 2).

\section{考察}

心蔵血管系手術中の大血管損傷はまれとはい え，遮断鉗子によるものや冠状動脈バイパス近位 側吻合部によるものなどの報告がみられる ${ }^{3 \sim 7)}$. これらは手術操作の遂行を困難にし, 術後合併症 を誘発する可能性を有するのみならず，適切な対 処を行い得なかった場合には，なによりも生命予 
表 2 周術期治療経過の内訳

\begin{tabular}{|c|c|c|c|c|c|}
\hline 症 例 & 1 & 2 & 3 & 4 & 5 \\
\hline 体外循環までの所要(分) & 22 & 8 & 126 & 25 & $-*$ \\
\hline 体外循環時間 (分) & 241 & 367 & 159 & 196 & 230 \\
\hline 循環停止温度 $\left({ }^{\circ} \mathrm{C}\right)$ & 21.8 & 21.4 & 20.4 & 22.0 & 19.5 \\
\hline 循環停止時間(分) & 44 & 42 & 37 & 20 & 27 \\
\hline 逆行性脳灌流法の併用 & - & + & - & - & + \\
\hline 術中同種血輸血量 (U) & 10 & 26 & 10 & 0 & 10 \\
\hline 術後覚醒時間 (時間) & $-* *$ & 9 & 8 & 4 & 7 \\
\hline 抜管までの日数 (日) & 25 & 8 & 1 & 3 & 3 \\
\hline 経口摂取までの日数(日) & 25 & 9 & 1 & 4 & 39 \\
\hline 神経学的合併症 & - & - & - & - & - \\
\hline 術後合併症 & $\begin{array}{c}\text { 仮性動脈瘤 } \\
\text { 形成 }\end{array}$ & $\begin{array}{c}\text { 左下肢動脈 } \\
\text { 閉塞 }\end{array}$ & - & - & 声带浮腫 \\
\hline 術後退院までの日数 (日) & 165 & 51 & 11 & 13 & 75 \\
\hline
\end{tabular}

*体外循環中。**持続鎮静降圧療法を施行したため評価し得ず。

後を左右する重大な事態となる。

術中急性大動脈解離に関しては, 発見次第修復 の要否を判断することが比較的容易であると考え られるが，血管損傷による出血の場合には，程度 が軽ければそのままで修復可能なものや，遮断鉗 子を用いて修復可能なものも数多くあると考えら

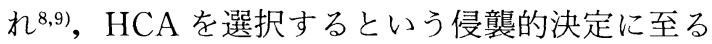
には相当の判断力が必要とされる.

本検討でも体外循環予定手術での損傷発生に際 しては，迅速に対処可能であったが，当初より体 外循環を予定していなかった症例では, 体外循環 を装着すること自体を躊躇するあまり，対処する までに長時間を要した。これらの経験より, 出血 性損傷の際の治療方針として, 最初は可能な限 り，直接修復あるいは遮断鉗子下での修復を試み ること.しかし再出血した際には，同様の手技を 繰り返すことにより，さらに副損傷を大きくする ので，圧迫止血が可能で循環動態が安定している うちに，速やかに確実性の高い HCA を選択する べきであると考えた。

弓部大動脈近傍の大血管損傷の要因としては, 流体力学的, 解剖学的特徵が潜在していると考え

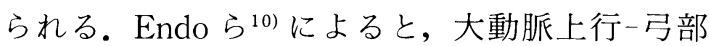
は構造上 shear stress が大彎側前壁に最も強くか かる部位とされている。そのため，血圧が充分に ある心拍動下での操作は, 過度の壁張力がかかり
やすいと想定される，一方，動脈管付近では血流 による血管壁にかかる shear stress は少ないもの の, 組織学的に中膜構造の脆弱性が存在すること から ${ }^{11 \sim 13)}$, 近傍の剥離に際して血管壁の損傷が おこりやすいとされる ${ }^{14)}$.

弓部大動脈近傍の修復に際しての HCA には, （1）血管壁の緊張緩和.（2）良好な無血視野. (3) 自己血回収が可能.（4) 低体温による臟器保 護。などの利点がある。脳保護許容時間につい て, 実験的検討では $18^{\circ} \mathrm{C}$ 以下で 60 分が一般的と されているが，ヒトでは安全域はさらに狭く，45 分を越えると脳障害が発生する危険が大であると されている ${ }^{15,16)}$. 本検討では循環停止開始時の深 部体温（膀胱温）は平均 $21.0^{\circ} \mathrm{C}$, 循環停止時間 は平均 34 分であり, HCA 単独でも脳障害の発 生する可能性は低いと考えられるが, 循環停止中 に逆行性脳灌流法（灌流圧 $20 \sim 30 \mathrm{mmHg}$ ）を 5 例中 2 例に利用し結果的にはなんら脳神経学的合 併症を認めなかった。脳保護時間の安全域を延長 させる方法として，危急の際にも，逆行性脳灌流 法は有用な脳保護補助手段のひとつであると考え られた ${ }^{17)}$.

一方, HCA の不利な点として, 冷却, 復温に よる手術時間の延長, 出血量の増加が問題とな る. 本検討でも，1例を除き同種血の輸血を余儀 なくされた。このような損傷の修復方法について 
論じることは, 確実な手技, 操作にまさるもので ないことはいうまでもない.しかしいったん大血 管の損傷が発生しても冷静に状況を把握し, 必要 ならば躊躇することなく HCA を選択することに より, 重大な合併症を回避しうる可能性があると 考えられる。

\section{結語}

弓部大動脈近傍の術中大動脈損傷に際し $\mathrm{HCA}$ を利用し修復を試みた。幸いにして全例救命で き，その治療方針について考察を加えた。

\section{文献}

1）長谷川伸之, 布施勝生, 加藤盛人ほか：動脈管開 存症術後に発症した MRSA 膿胸, 仮性動脈瘤の 1 救命例. 日心外会誌 $26: 400-403,1997$.

2）齊藤 力, 布施勝生, 加藤盛人ほか：逆行性送血 による術中急性大動脈解離の 1 治験例. 日胸外会 誌 $44 ：$ 1953-1957, 1996.

3) Boruchow, I. B., Iyenger, R. and Jude, J. R. : Injury to ascending aorta by partial-occlusion clamp during aorta-coronary bypass. J. Thorac. Cardiovasc. Surg. 73: 303-305, 1977.

4) Litchford, B., Okies, J. E., Sugimura, S. et al. : Acute aortic dissection from cross-clamp injury. J. Thorac. Cardiovasc. Surg. 72 : 709713, 1976.

5) Standefer, R. J., Livermore, J. and Khonsari, S. : Disruption of the ascending aorta: surgical management. Ann. Thorac. Surg. 41: 9597, 1986.

6) Nicholson, W. J., Crawly, I. S., Logue, R. B. et al. : Aortic root dissection complicating coronary bypass surgery. Am. J. Cardiol. 41 : 103107, 1978.

7) Still, R. J., Hilgenberg, A. D., Akins, C. W. et al.: Intraoperative aortic dissection. Ann. Thorac. Surg. 53 : 374-380, 1992.

8) Antunes, M. J. : Acute traumatic rupture of the aorta: repair by simple aortic cross-clamping.
Ann. Thorac. Surg. 44 : 257-259, 1987.

9) Murphy, D. A., Craver, J. M., Jones, E. L. et al. : Recognition and management of ascending aortic dissection complicating cardiac surgical operations. J. Thorac. Cardiovasc. Surg. 85 : 247-256, 1983.

10) Endo, S., Sohara, Y. and Karino, T.: Flow patterns in dog aortic arch under a steady flow condition simulating mid-systole. Heart Vessels 11: 180-191, 1996.

11) Gittenberger-de Groot, A. C. : Persistent ductus arteriosus: most probably a primary congenital malformation. Br. Heart J. 39: 610-618, 1977.

12) Slomp, J., van Munsteren, J. C., Poelmann, R. E. et al. : Formation of intimal cushions in the ductus arteriosus as a model for vascular intimal thickening. An immunohistochemical study of changes in extracellular matrix components. Atherosclerosis 93: 25-39, 1992.

13) Gittenberger-de Groot, A.C., Strengers, J. L., Mentink, M. et al.: Histologic studies on normal and persistent ductus arteriosus in the dog. J. Am. Coll. Cardiol. 6 : 394-404, 1985.

14) Khonsari, S.: Cardiac Surgery: Safeguards and pitfalls in operative technique: patent ductus arteriosus, Lippincott-Raven Publishers, Philadelphia, 1997, pp. 171-176.

15) O'Connor, J. V., Wilding, T., Farmer, P. et al. : The protective effect of profound hypothermia on the canine central nervous system in surgery of the ascending aorta and the aortic arch. Ann. Thorac. Surg. 41 : 255-259, 1986.

16) Cooley, D. A., Ott, D. A., Frazier, O. H. et al. : Surgical treatment of aneurysms of the transverse aortic arch: experience with 25 patients using hypothermic techniques. Ann. Thrac. Surg. 32 : 260-272, 1981.

17) Deeb, G. M., Jenkins, E., Bolling, S. F. et al. : Retrograde cerebral perfusion during hypothermic circulatory arrest reduces neurologic morbidity. J. Thorac. Cardiovasc. Surg. 109 : 259268, 1995. 